\title{
Multimodality imaging of spermatic cord abscess
}

\author{
Ali Kemal Sivrioglu, ${ }^{1}$ Mehmet Incedayi, ${ }^{2}$ Hasan Saygin, ${ }^{2}$ Guner Sonmez ${ }^{2}$
}

${ }^{1}$ Radiology Department, Aksaz Military Hospital, Mugla, Turkey

${ }^{2}$ Department of Radiology, GATA Haydarpasa Teaching Hospital, Istanbul, Turkey

\section{Correspondence to} Dr Mehmet Incedayi, m_incedayi@yahoo.com
To cite: Sivrioglu AK, Incedayi $\mathrm{M}$, Saygin $\mathrm{H}$, et al. BMJ Case Rep Published online: [please include Day Month Year] doi:10.1136/ bcr-2013-008899

\section{DESCRIPTION}

A 21-year-old man was admitted to the urology department due to swelling and pain in the left inguinal region. On initial physical examination, he was slightly febrile, and areas of induration with tenderness were palpated in the left inguinal region and left hemiscrotum. Laboratory tests showed leukocytosis $\left(14000 / \mathrm{mm}^{3}\right)$ and elevated $\mathrm{C}$ reactive protein $(12 \mathrm{mg} / \mathrm{dL})$. On ultrasound left epididymo-orchitis and expansion of the left inguinal canal were seen. In addition, a cystic tubular mass with wall thickness that had displaced the bladder was seen in the left hemipelvis (figure 1). Contrast-enhanced CT revealed a cystic tubular mass with marked marginal enhancement from the left inguinal canal to the left seminal vesicle. On MRI the finding of left epididimo-orsitis and expansion of the left spermatic cord with tubular fluid collection was determined. On contrast-enhanced MRI the left spermatic cord abscess was confirmed. Abscess formation of the prostate tissue was not observed. Moreover, the mild wall enhancement of the seminal vesicle and mild cystic dilation were seen.
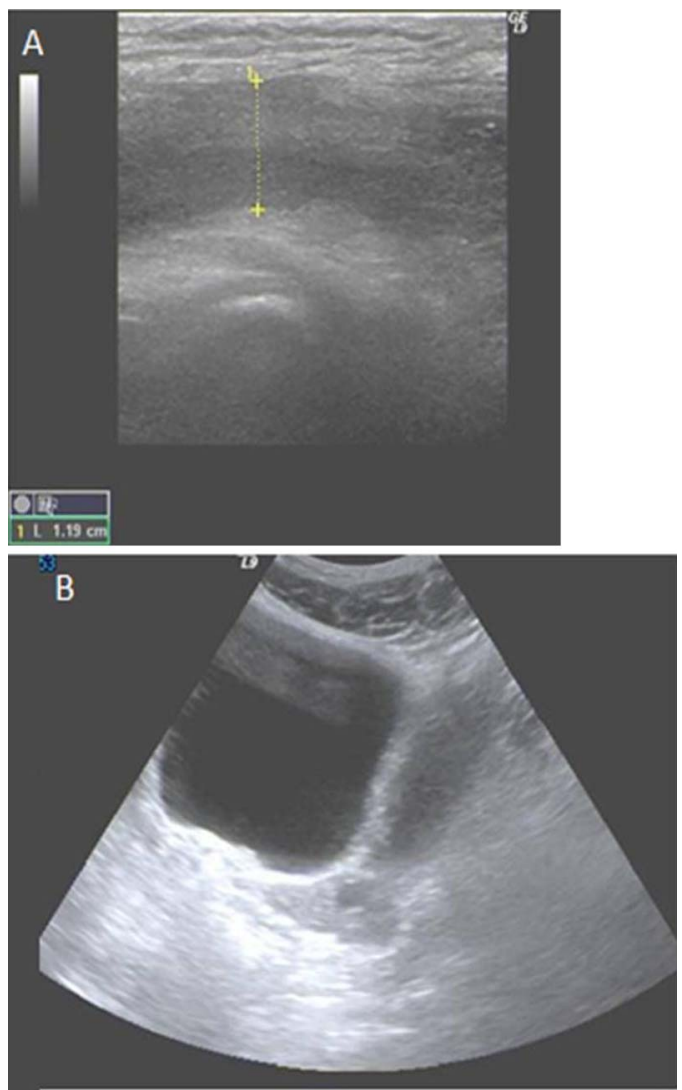

Figure 1 Ultrasound images show expansion of the left inguinal canal (A) and a cystic tubular mass with wall thickness that had displaced bladder in the left hemipelvis (B).

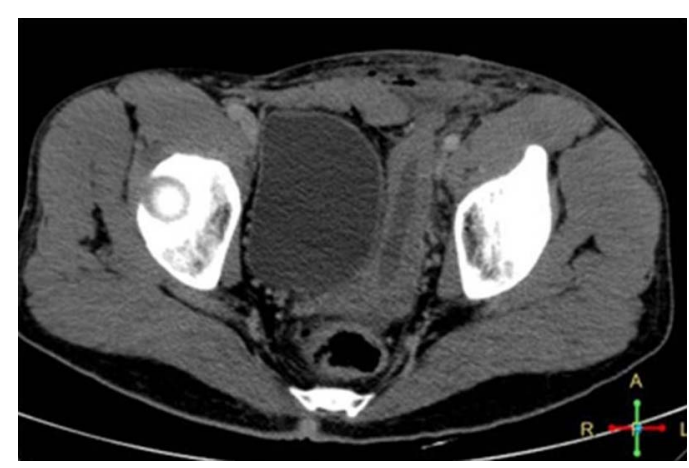

Figure 2 Contrast-enhanced CT image shows a cystic tubular mass with marked marginal enhancement from the left inguinal canal to the left seminal vesicle.

Surgical intervention was not considered in the first place due to the reduction in the patient"s complaints after treatment with antibiotics and localised spermatic cord abscess. He was discharged 15 days after being admitted to the hospital (figures 2-4).
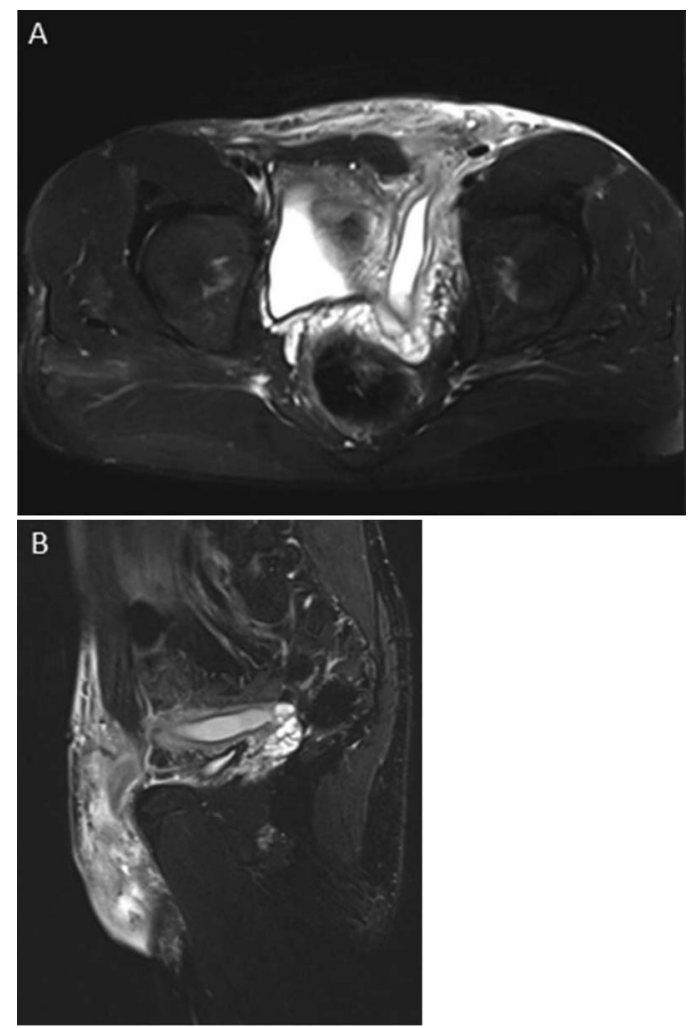

Figure 3 Axial (A) and sagittal (B) T2-weighted MRI show the finding of left epididimo-orsitis, expansion of the left spermatic cord with tubular fluid collection and subcutaneous oedema of the left inguinal area. 

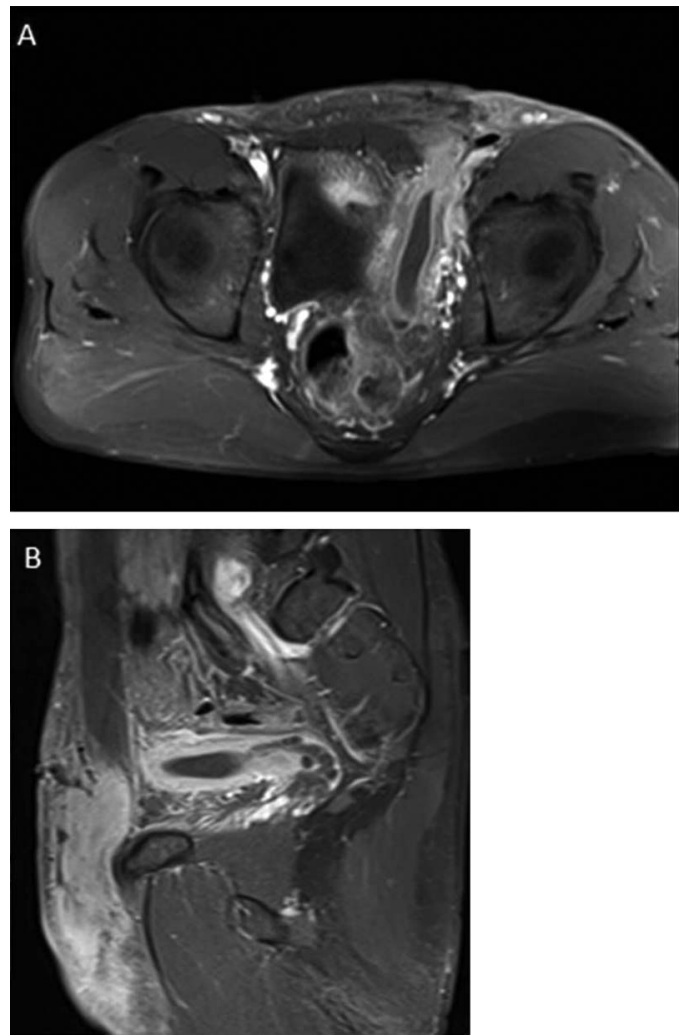

Figure 4 Axial (A) and sagittal (B) contrast-enhanced MRI show left spermatic cord abscess.
Spermatic cord abscess is generally secondary to inflammation of the prostate. The suggested pathological mechanism is that a retrograde urinary infection moves through the ductus deferens to the spermatic cord. ${ }^{1}$ In the literature spermatic cord abscesses due to Escherichia coli and Candida have been determined in two different cases. $^{1}{ }^{2}$ To our knowledge, ours is the third report in the literature. However, ours is the first case that did not have chronic diseases.

\section{Learning point}

- On imaging modalities, spermatic cord abscess should be considered when cystic tubuler mass is seen in hemipelvis.

Competing interests None.

Patient consent Obtained.

Provenance and peer review Not commissioned; externally peer reviewed.

\section{REFERENCES}

1 Machida $H$, Ueno $E$, Nakazawa $H$, et al. Spermatic cord abscess with concurrent prostatic abscess involving the seminal vesicle. Radiat Med 2008;26:81-3.

2 Ishida K, Yuhara K, Kanimoto $Y$, et al. A case of mycotic spermatic cord abscess in a continuous ambulatory peritoneal dialysis patient. Hinyokika Kiyo 2005;51:37-9.

Copyright 2013 BMJ Publishing Group. All rights reserved. For permission to reuse any of this content visit http://group.bmj.com/group/rights-licensing/permissions.

BMJ Case Report Fellows may re-use this article for personal use and teaching without any further permission.

Become a Fellow of BMJ Case Reports today and you can:

- Submit as many cases as you like

- Enjoy fast sympathetic peer review and rapid publication of accepted articles

- Access all the published articles

- Re-use any of the published material for personal use and teaching without further permission

For information on Institutional Fellowships contact consortiasales@bmjgroup.com

Visit casereports.bmj.com for more articles like this and to become a Fellow 